\title{
PENERAPAN MODEL PEMBELAJARAN KOOPERATIF JIGSAW DENGAN PETA PIKIRAN UNTUK MENINGKATKAN MOTIVASI DAN HASIL BELAJAR AKUNTANSI SISWA
}

\author{
M. Hasib \\ SMP Sriwedari Jl Bogor Atas No. 1 Malang \\ aysrohan@yahoo.co.id
}

\begin{abstract}
The Classroom Action Research (PTK) aimed to increase motivation and learning outcomes by applying the Jigsaw cooperative learning model combined with mind maps. The subjects were 37 students of class X MA Al-Ula Ambat Tlanakan Pamekasan. Motivation data were obtained through observations, while the student learning outcomes data were obtained through test at the end of each cycle. The result showed that the model enhance student motivation and learning outcomes. Thus it can be suggested that teachers may use jigsaw cooperative learning model combine with mind maps on the subject (other than accounting and information systems) to increase motivation and learning outcomes of accounting students.
\end{abstract}

Keywords: Clasroom Action Reseach (PTK), Cooperative, Jigsaw, Mind Map.

\begin{abstract}
Abstrak: Penelitian Tindakan Kelas (PTK) ini bertujuan untuk meningkatkan motivasi dan hasil belajar akuntansi siswa dengan menerapkan model pembelajaran kooperatif jigsaw yang dipadukan dengan peta pikiran. Subjek penelitian adalah siswa kelas X MA Al-Ula Ambat Tlanakan Pamekasan yang berjumlah 37 siswa. Data motivasi belajar siswa diperoleh melalui observasi, sedangkan data hasil belajar siswa diperoleh melalui tes pada setiap akhir siklus. Hasil penelitian menunjukkan bahwa model pembelajaran kooperatif jigsaw dengan peta pikiran dapat meningkatkan motivasi dan hasil belajar siswa. Dengan demikian dapat disarankan bahwa guru dapat menggunakan model pembelajaran kooperatif jigsaw dengan peta pikiran pada pokok bahasan yang lain (selain akuntansi dan sistem informasi) untuk meningkatkan motivasi dan hasil belajar akuntansi siswa.
\end{abstract}

Kata Kunci: PTK, Kooperatif, Jigsaw, Peta Pikiran.

MA Al-Ula Ambat Tlanakan Pamekasan merupakan salah satu sekolah swasta yang beralamatkan di jalan raya Tlanakan Pamekasan Madura. Dari segi fasilitas, sekolah ini tidak jauh berbeda dengan MA Negeri yang ada di sekitarnya. Berdasarkan observasi yang dilakukan di MA Al-Ula Ambat Tlanakan Pamekasan, masalah mendasar yang terjadi pada saat proses pembelajaran berlangsung adalah ketika guru mengajukan pertanyaan hanya siswa yang bertempat duduk di depan yang aktif yaitu selalu 
memperhatikan, dan dapat menjawab pertanyaan guru, sedangkan siswa yang duduk di belakang asyik bermain, berbicara dengan teman sebangku, mencorat-coret buku, dan menggambar. Ketika guru meminta siswa mencatat materi yang penting dengan cara mendikte untuk memusatkan perhatian siswa, siswa banyak mengeluh karena karena materi terlalu panjang dan banyak. Hal itu membuat siswa malas mencatat dan tidak memiliki pegangan untuk dipelajari menjelang ujian. Oleh karena itu, diperlukan suatu perbaikan dalam proses pembelajaran untuk meningkatkan motivasi dan hasil belajar siswa yaitu dengan cara menumbuhkan keinginan siswa aktif di kelas, mencatat lebih baik, memahami, dan mengingat materi yang dijelaskan.

Upaya untuk mengaktifkan siswa di kelas dapat dilakukan dengan pembelajaran kooperatif. Pembelajaran kooperatif merupakan metode pembelajaran yang didasarkan atas kerja kelompok yang dilakukan untuk mencapai tujuan khusus (Santoso \& Suparno, 2003: 5). Nurhadi \& Senduk (2004: 64) menjelaskan bahwa model pembelajaran yang berbasis belajar kooperatif ada beberapa macam, antara lain model pembelajaran kooperatif Student Teams Achievement Divisions (STAD), Jigsaw, Group Investigation (GI), Numbered Heads Together (NHT), dan Think Pair Share (TPS).

Penelitian ini menggunakan Model Pembelajaran Kooperatif Jigsaw. Menurut Susanto (1999: 49) model pembelajaran kooperatif jigsaw adalah suatu strategi pembelajaran yang dirancang agar siswa mempelajari informasi yang berbeda dan tingkat tinggi melalui kerja kelompok (masing-masing kelompok beranggotakan 4 orang). Tiap siswa dalam kelompok diberi bagian materi yang berbeda (kelompok asal). Tiap siswa dalam kelompok membaca materi yang ditugaskan, anggota kelompok yang berbeda yang telah mempelajari bagian/sub bab yang sama bertemu dalam kelompok baru (kelompok ahli). Anggota kelompok ahli ini saling mengajarkan dan mendiskusikan perolehannya, sampai semua anggota menguasai sub topik yang dikerjakan. Setelah selesai diskusi dalam kelompok ahli, setiap siswa kembali ke kelompok asal dan bergantian mengajar teman kelompok asal tentang subbab yang dikuasai dan tiap anggota lainnya mendengarkan dengan sungguh-sungguh. Selanjutnya guru dan siswa membuat kesimpulan, lalu guru memberi evaluasi.

Dengan penggunaan Model Pembelajaran Kooperatif Jigsaw diharapkan dapat membangun suasana belajar yang semula hanya berpusat pada guru (Teacher Centered) menjadi berpusat pada siswa (Student Centered). Perubahan suasana belajar membuat siswa lebih berminat untuk mempelajari akuntansi. Siswa dapat memperoleh pengetahuan yang lebih berarti dengan membangun sendiri konsep yang diperoleh. Terdapat beberapa 
kendala ketika siswa belajar membangun konsep, yaitu: (1) siswa sulit konsentrasi ketika berusaha mengingat kembali apa yang sudah didapatkan, dipelajari, direkam, dicatat atau yang dahulu pernah diingat, dan (2) siswa sulit mengerjakan tugas karena catatan ataupun ingatannya belum teratur. Oleh karena itu dibutuhkan suatu alat untuk membantu otak berpikir secara teratur, yakni peta pikiran (Gardu Guru, 2008).

Peta pikiran (mind map) adalah cara termudah menempatkan informasi ke dalam otak dan mengambil informasi ke luar dari otak (Buzan, 2006: 4). Peta pikiran ini didasarkan pada riset tentang bagaimana cara kerja otak sebenarnya, dimana otak berfungsi untuk mengatur dan menyimpan informasi. Hal ini disebabkan karena otak manusia seringkali mengingat informasi dalam bentuk gambar, simbol, suara, bentukbentuk, dan perasaan (Bobbi \& Hernacki, 1992: 152). Peta pikiran memiliki banyak manfaat, yaitu membantu dalam mengingat, mendapatkan ide, menghemat waktu, berkonsentrasi, mendapatkan nilai yang lebih bagus, mengatur pikiran dan hobi, media bermain, bersenang-senang dalam menuangkan imajinasi yang tentunya memunculkan kreativitas (Gardu Guru, 2008). Apabila menggunakan model pembelajaran peta pikiran, siswa dapat menggunakan otak kiri untuk berpikir dan menggunakan otak kanan untuk menulis dan menggambar sehingga siswa belajar dengan melibatkan kedua belah otak.

Berdasarkan uraian latar belakang di atas, maka penelitian tentang penerapan model pembelajaran kooperatif jigsaw dengan peta pikiran untuk meningkatkan motivasi dan hasil belajar akuntansi siswa kelas X MA Al-Ula Ambat Tlanakan Pamekasan perlu dilakukan.

\section{METODE}

Penelitian ini adalah penelitian PTK (Penelitian Tindakan Kelas). Berdasarkan dari tujuannya, PTK dilaksanakan untuk mengadakan perbaikan dan peningkatan pelaksanaan pembelajaran yang ada di kelas dan hasilnya tidak untuk digeneralisasikan. Prosedur dan langkah-lagkah dalam penelitian tindakan kelas ini mengikuti prinsip dasar penelitian tindakan yaitu menggunakan prosedur kerja dengan satu siklus, yang terdiri dari empat langkah yaitu perencanaan tindakan (plan), pelaksanaan (action), observasi (observation), dan refleksi (reflection). Secara umum alur pelaksanaan tindakan dalam penelitian tindakan kelas ini digambarkan pada gambar sebagai berikut. 


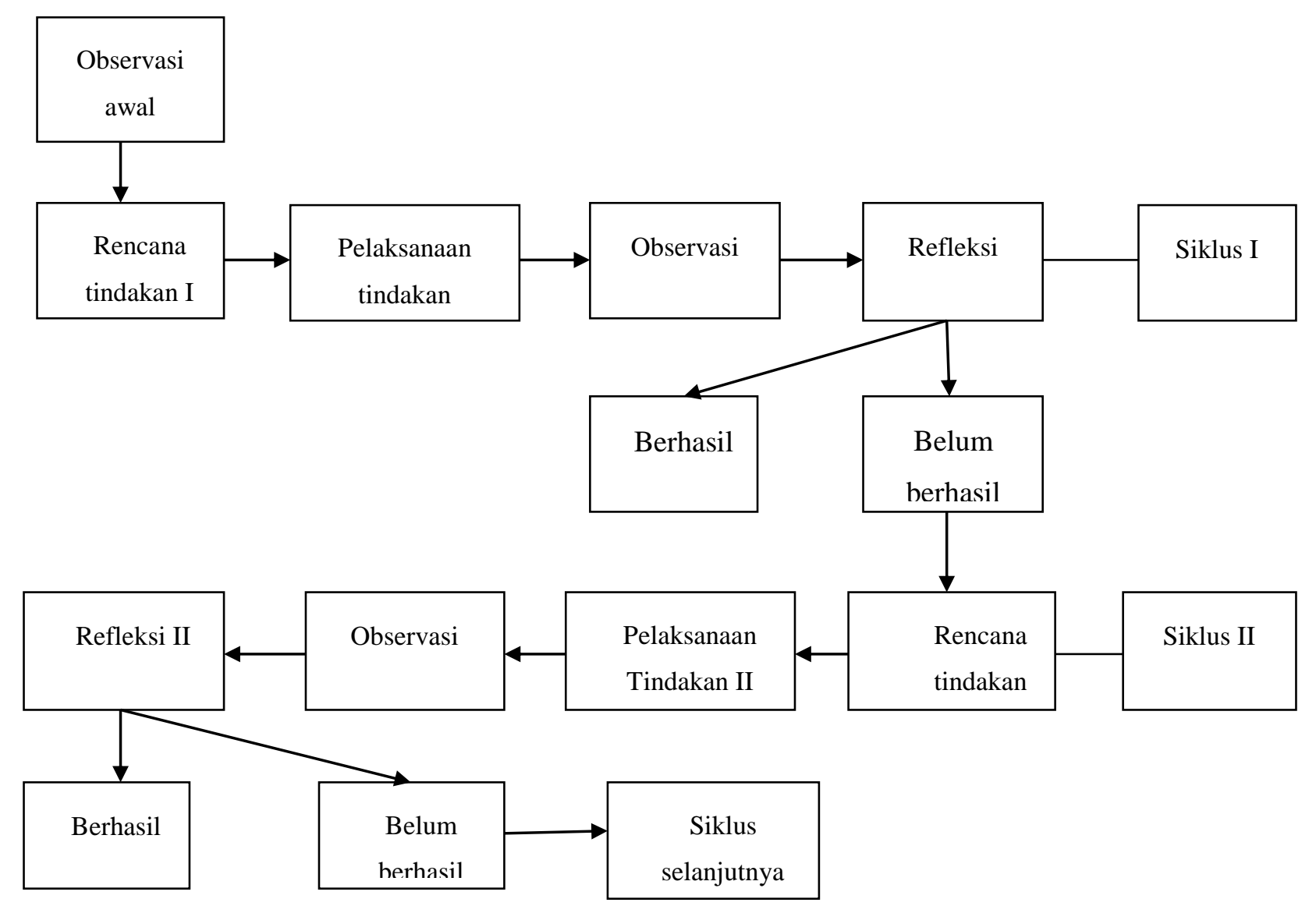

Gambar 1. Alur Pelaksanaan Tindakan dalam Penelitian Tindakan Kelas (Kasihani, dkk., 2006: 9)

Dalam melakukan penelitian, peneliti berperan sebagai perancang tindakan dan sebagai fasilitator agar proses belajar pembelajaran lebih aktif. Tempat pelaksanaan penelitian adalah MA Al-Ula Ambat Tlanakan Pamekasan dengan subjek penelitian adalah siswa kelas $\mathrm{X}$ yang terdiri dari 37 siswa.

Jenis data primer dalam penelitian ini adalah data yang bersumber langsung dari subyek penelitian yaitu siswa kelas X MA Al-Ula Ambat Tlanakan Pamekasan. Teknik pengumpulan data adalah tes, wawancara, dan observasi. Teknik analisis yang digunakan dalam penelitian ini terdiri dari tiga tahap yaitu reduksi data, penyajian data, dan penarikan kesimpulan Moloeng (2000). 


\section{HASIL DAN PEMBAHASAN}

\section{Hasil}

Siklus I

Perencanaan tindakan didahului dengan proses wawancara dan observasi untuk mengetahui motivasi, hasil belajar siswa, serta proses belajar mengajar sebelum menggunakan model pembelajaran kooperatif jigsaw dengan peta pikiran. Berdasarkan hasil wawancara dan observasi tersebut peneliti menyusun rencana pembelajaran sebagai pedoman dalam pelaksanaan tindakan pada siklus I.

Tabel 1. Rencana Pembelajaran Siklus I

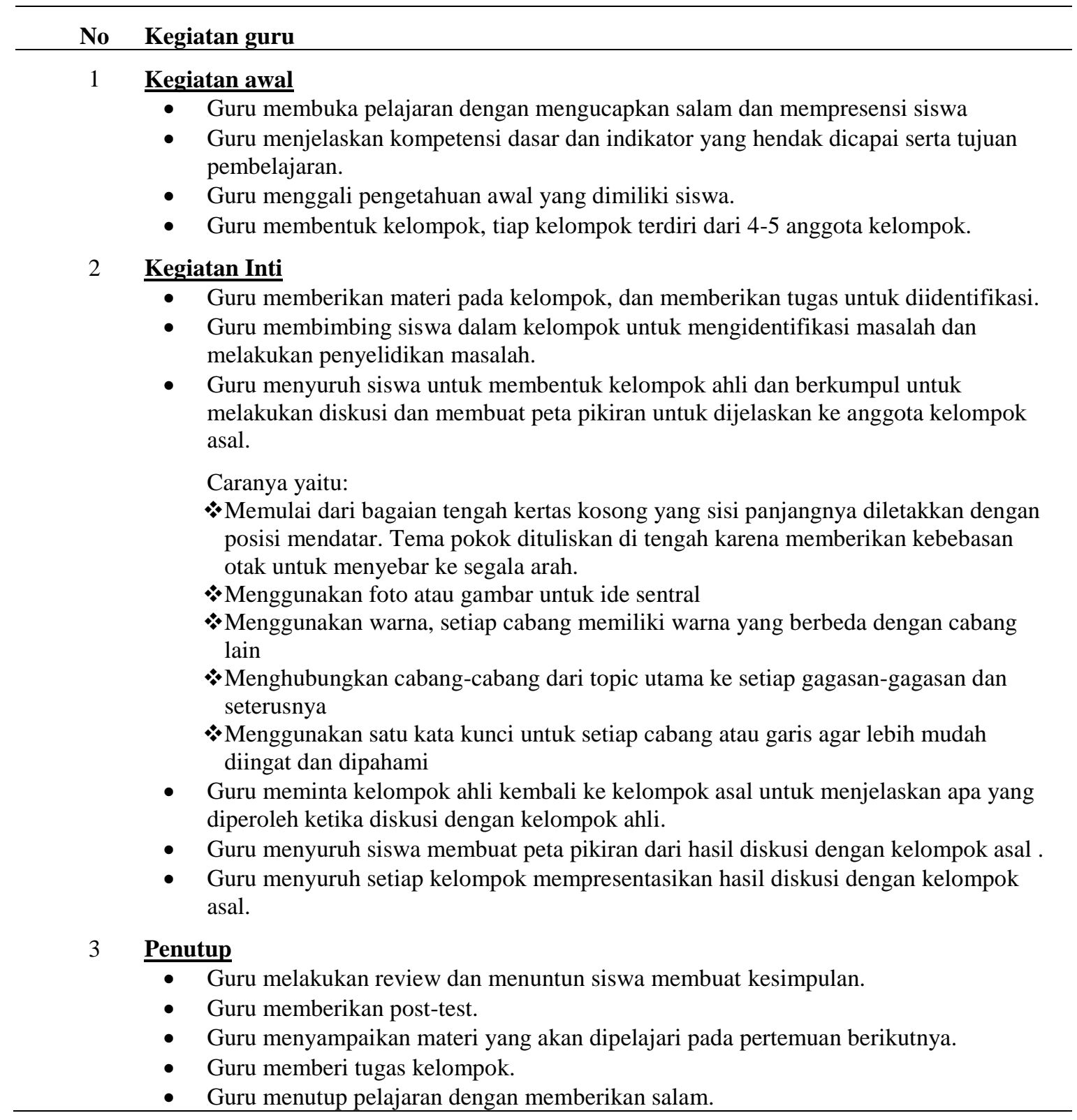


Setelah dilaksanakan tindakan pada siklus I, dilakukan observasi. Hasil observasi menunjukkan bahwa siswa termotivasi untuk belajar dan bekerjasama dengan anggota kelompok masing-masing. Dari indikator motivasi, diperoleh nilai aspek perhatian sebesar 76,5\%, usaha 78,3\%, ekstensi 77,0\%, dan penampilan 76,1\%. Meski demikian, terdapat beberapa siswa yang tidak serius mengikuti kegiatan belajar mengajar. Ini dibuktkan dengan adanya beberapa indikator motivasi yang nilainya dibawah Standar Ketuntasan Minimal (SKM) yaitu aspek lama belajar sebesar 71,0\% dan irama perasaan $68,3 \%$.

Hasil belajar siklus I menunjukkan bahwa masih banyak siswa yang belum memperoleh nilai di atas standar ketuntasan minimal. Dari 37 siswa, 20 siswa memenuhi SKM dan 17 siswa nilainya masih di bawah SKM, sehingga rata-rata kelas sebesar 68,24 dengan ketuntasan belajar mencapai 54,05\%. Merefleksi dari hasil siklus I ini, maka peneliti merancang siklus II untuk memperbaiki kekurangan yang terjadi pada siklus I.

\section{Siklus II}

Hasil refleksi siklus I dipedomani dalam rangka menyusun perencanaan tindakan pada siklus II. Berikut rencana pembelajaran yang dilakukan pada siklus II.

\section{Tabel 2. Rencana Pembelajaran Siklus II}

\section{No Kegiatan guru}

\section{$1 \quad$ Kegiatan awal}

- Guru membuka pelajaran dengan mengucapkan salam dan mempresensi siswa

- Guru menjelaskan kompetensi dasar dan indikator yang hendak dicapai serta tujuan pembelajaran.

- Guru menggali pengetahuan awal yang dimiliki siswa.

- Guru membentuk kelompok, tiap kelompok terdiri dari 4-5 anggota kelompok.

\section{Kegiatan Inti}

- Guru memberikan materi pada kelompok, dan memberikan tugas untuk diidentifikasi.

- Guru membimbing siswa dalam kelompok untuk mengidentifikasi masalah dan melakukan penyelidikan masalah.

- Guru menyuruh siswa untuk membentuk kelompok ahli dan berkumpul untuk melakukan diskusi dan membuat peta pikiran untuk dijelaskan ke anggota kelompok asal.

Caranya yaitu:

* Memulai dari bagaian tengah kertas kosong yang sisi panjangnya diletakkan dengan posisi mendatar. Tema pokok dituliskan di tengah karena memberikan kebebasan otak untuk menyebar ke segala arah.

* Menggunakan foto atau gambar untuk ide sentral

* Menggunakan warna, setiap cabang memiliki warna yang berbeda dengan cabang lain 
* Menghubungkan cabang-cabang dari topic utama ke setiap gagasan-gagasan dan seterusnya

* Menggunakan satu kata kunci untuk setiap cabang atau garis agar lebih mudah diingat dan dipahami

- Guru meminta kelompok ahli kembali ke kelompok asal untuk menjelaskan apa yang diperoleh ketika diskusi dengan kelompok ahli.

- Guru menyuruh siswa membuat peta pikiran dari hasil diskusi dengan kelompok asal .

- Guru menyuruh setiap kelompok mempresentasikan hasil diskusi dengan kelompok asal.

- Guru melakukan review dan menuntun siswa membuat kesimpulan.

- Guru memberikan post-test.

- Guru menyampaikan materi yang akan dipelajari pada pertemuan berikutnya.

- Guru memberi tugas kelompok.

- Guru menutup pelajaran dengan memberikan salam.

Observasi pasca tindakan pada siklus II menunjukkan bahwa siswa lebih termotivasi untuk belajar dan bekerjasama dengan anggota kelompok masing-masing. Semua indikator motivasi memperoleh nilai di atas SKM yaitu perhatian dengan nilai $77,7 \%$, lama belajar dengan nilai $79,2 \%$, usaha dengan nilai $80,1 \%$, irama perasaan dengan nilai $82,2 \%$, ekstensi $84,6 \%$, dan penampilan $80,7 \%$.

Hasil belajar siswa pada siklus II lebih baik daripada siklus I. Dari 37 siswa, 33 siswa memenuhi SKM dan 4 siswa nilainya masih di bawah SKM, sehingga rata-rata kelas sebesar 77,70 dengan ketuntasan belajar mencapai 89,18\%.

\section{Pembahasan}

\section{Peningkatan Motivasi Belajar Siswa Setelah Menerapkan Model Pembelajaran}

\section{Kooperatif Jigsaw dengan Peta Pikiran.}

Keberhasilan seseorang dapat terjadi karena dorongan dan kemauan dari dalam diri pribadi orang itu sendiri. Begitu juga pada proses belajar, seseorang akan berhasil dalam belajar apabila pada dirinya terdapat keinginan untuk belajar. Inilah prinsip dalam kegiatan pendidikan dan pengajaran. Keinginan atau dorongan inilah menjadi daya penggerak yang menyebabkan seseorang melakukan sesuatu perbuatan dengan cara tertentu untuk memperoleh sesuatu yang diharapkan (Moeslichatoen, 1992:2). Dalam motivasi terkandung adanya keinginan, harapan, kebutuhan, tujuan, sasaran dan intensif. Keadaan kejiwaan inilah yang mengaktifkan, menggerakkan, menyalurkan, dan mmengarahkan sikap dan perilaku belajar (Dimyati \& Mudjiono, 2006:75). 
Proses pembelajaran yang dapat menimbulkan motivasi siswa untuk belajar dan memperoleh hasil belajar yang maksimal merupakan salah satu tujuan guru dalam mengajar. Pembelajaran kooperatif diyakini dapat meningkatkan motivasi siswa. Hal ini didukung oleh pernyataan Nurhadi, dkk., (2004: 64) bahwa pembelajaran kooperatif mampu meningkatkan motivasi intrinsik siswa. Tujuan pembelajaran kooperatif yaitu: (1) meningkatkan kemampuan akademik melalui kolaborasi kelompok; (2) memperbaiki hubungan antara siswa yang berbeda latar belakang etnik dan kemampuannya; (3) mengembangkan keterampilan untuk memecahkan masalah melalui kelompok; dan (4) mendorong proses demokrasi di kelas (Barba dalam Susanto, 1999: 46).

Motivasi belajar siswa pada siklus I belum maksimal dengan taraf keberhasilan yang diperoleh sebesar 74,5\% yang masuk kategori cukup. Siswa belum terbiasa belajar dengan menggunakan pembelajaran kooperatif sehingga siswa belum bisa memahami tujuan dari pembelajaran kooperatif itu sendiri dengan baik. Oleh karena itu guru harus berusaha memberikan pengertian dan pengarahan tentang tujuan serta cara melakukan pembelajaran menggunakan model pembelajaran kooperatif jigsaw dengan peta pikiran agar siswa dapat meningkatkan motivasinya untuk belajar. Hal tersebut dapat dilihat dari taraf keberhasilan yang diperoleh siswa pada siklus II yaitu sebesar 80,75\% yang dikategorikan baik. Ini menunjukkan bahwa rumusan tujuan pembelajaran yang disampaikan guru dapat diterima dengan baik oleh siswa sehingga timbul gairah pada siswa untuk terus belajar dan mencapai apa yang diharapkan.

Motivasi belajar dapat ditandai dengan 6 macam tingkah laku sebagaimana yang diukur dalam penelitian ini, yaitu perhatian, lama belajar, usaha, irama perasaan, ekstensi dan penampilan (Susanto, 2002). Pada indikator perhatian, terjadi peningkatan sebesar 1,2\% dimana pada siklus I adalah sebesar 76,5\% dengan kategori baik dan pada siklus II menjadi $77,7 \%$ dengan kategori baik. Motivasi belajar dapat tinggi jika siswa memusatkan perhatian pada kegiatan belajar lebih besar daripada tingkah laku yang bukan kegiatan belajar (Anderson \& Fraust dalam Susanto, 2002: 45). Seorang siswa yang memiliki motivasi belajar yang tinggi akan menampakkan minat dan perhatian yang penuh terhadap tugas-tugas belajar. Mereka akan memusatkan sebanyak mungkin energi fisik maupun psikis terhadap kegiatan belajar tanpa mengenal perasaan bosan apalagi menyerah. Sebaliknya siswa yang memiliki motivasi rendah dalam belajar akan menampakkan keengganan, bosan, bersifat pasif, dan berusaha menghindar dari aktivitas dan tugas belajar. Hal tersebut sesuai dengan pendapat Dimyati \& Mudjiono (2006: 2) 
yang mengatakan bahwa perhatian mempunyai peranan yang penting dalam kegiatan pembelajaran. Tanpa adanya perhatian tidak mungkin terjadi aktivitas belajar. Perhatian terhadap pelajaran akan timbul pada diri siswa apabila bahan pelajaran tersebut sesuai atau berhubungan dengan kebutuhannya, sehingga siswa akan merasa bahan pelajaran tersebut sesuatu yang dibutuhkan dan akan membangkitkan motivasi untuk mempelajarinya. Hal ini ditunjukkan dengan antusiasnya siswa memperhatikan penjelasan guru.

Selain perhatian, indikator motivasi adalah lama belajar. Terjadi peningkatan lama belajar sebesar 8,2\% dimana pada siklus I persentase lama belajar adalah sebesar 71,0\% dengan kategori cukup dan pada siklus II menjadi 79,2\% dengan kategori baik. Indikator lama belajar dideskripsikan dengan siswa menyelesaikan tugas sesuai dengan waktu yang telah disediakan. Hal ini menunjukkan bahwa setiap siswa membutuhkan waktu yang tidak sedikit untuk menyelesaikan tugas di sekolah. Paradigma pendidikan masa kini yang menekankan pada pembelajaran yang berorientasi pada siswa menimbukan konsekuensi bagi siswa untuk makin banyak menyediakan waktu untuk belajar. Hal ini selaras dengan pendapat Dimyati \& Mudjiono (2006) yang menyatakan bahwa siswa harus dapat lebih berperan aktif dalam mengembangkan cara-cara belajar mandiri.

Pada indikator usaha belajar, terjadi peningkatan sebesar 1,8\%. Pada siklus I persentase indikator usaha belajar adalah sebesar 78,3\% dengan kategori baik menjadi $80,1 \%$ dengan kategori baik pada siklus II. Indikator usaha dideskripsikan sebagai kerja keras dan semangat anggota kelompok untuk memecahkan permasalahan yang ada. Hal ini mendukug pernyataan Sudjana (2001) bahwa usaha yang baik adalah usaha yang dilakukan dengan sngguh-sungguh dan kerja keras untuk menghasilkan apa yang diharapkan serta mendukung pernyataan Susanto (2002) bahwa siswa mempunyai motivasi yang tinggi jika siswa bekerja secara intensif, mengeluarkan banyak energi dan kemampuan untuk menyelesaikan tugas belajar.

Pada indikator irama perasaan, terjadi peningkatan sebesar 13,9\%. Pada siklus I persentase indikator irama perasaan adalah sebesar 68,3\% dengan kategori cukup dan pada siklus II menjadi $82,2 \%$ baik. Irama perasaan ini diidentifikasi dengan suasana hati siswa ketika mengikuti pembelajaran. Jika perasaan siswa senang, siswa cenderung bersemangat untuk belajar, tapi sebaliknya jika suasana hati siswa sedih atau ada masalah siswa cenderung malas dan tidak bersemangat untuk belajar. Hal itu sesuai pendapat Susanto (2002) yang menyatakan bahwa siswa mempunyai motivasi belajar yang tinggi 
jika siswa merasa gembira, mempunyai keyakinan diri dan tegar pada situasi belajar yang dialami.

Peningkatan indikator motivasi juga terjadi pada indikator ekstensi siswa. Pada siklus I diperoleh persentase sebesar 77,0\% dengan kategori baik meningkat menjadi 84,6\% dengan kategori baik pada siklus II. Pada aspek ekstensi ini siswa telah dapat menggunakan jam di luar sekolah atau bebas pelajaran dengan baik untuk mengerjakan semua tugas yang telah diberikan guru. Hasil ini mendukung pernyataan Dimyati \& Mudjiono (2006) bahwa siswa diharapkan akan lebih mampu mengenal dan mengembangkan kapasitas belajar dan potensi yang dimilikinya secara penuh, menyadari dan dapat menggunakan potensi sumber belajar yang terdapat disekitarnya, serta pernyataan Susanto (2002) bahwa siswa mempunyai motivasi belajar yang tinggi jika siswa menggunakan jam-jam bebas pelajaran atau istirahat untuk kegiatan belajar.

Pada indikator penampilan, terjadi peningkatan sebesar 4,6\%. Pada siklus I yang hanya mendapat $76,1 \%$ dengan kategori baik meningkat menjadi $80,7 \%$ pada siklus II dengan kategori baik. Penampilan belajar siswa dapat ditunjukkan dari keberanian siswa dalam menjelaskan materi pembelajaran, menunjukkan sikap paham terhadap materi dengan sikap percaya diri, tenang dan tidak gugup ketika menjawab pertanyaan yang diajukan angota kelompok lain ketika melakukan presentasi hasil diskusi. Hasil ini mendukung pendapat Geoch dalam Fathurrahman (2007) yang menyatakan bahwa siswa dikatakan belajar jika siswa tersebut menunjukkan adanya perubahan dalam penampilan sebagai akibat dari kegiatan yang dilakukannya selama belajar.

\section{Peningkatan Hasil Belajar Siswa Setelah Menerapkan Model Pembelajaran Kooperatif Jigsaw dengan Peta Pikiran.}

Winkel (1989) mengelompokkan tujuan pembelajaran ke dalam tiga ranah yaitu ranah kognitif, ranah afektif, dan ranah psikomotor. Pada penelitian ini ranah yang diamati adalah ranah kognitif. Ranah kognitif berorientasi pada kemampuan berpikir seseorang. Kemampuan ini dapat meliputi kemampuan berpikir yang mencakup intelektual yang sederhana sampai yang lebih kompleks. Ranah kognitif mencakup tujuan pembelajaran yang berkenaan dengan pengembangan kemampuan dan keterampilan intelektual serta pemahaman pengetahuan yang mendalam. 
Berdasarkan hasil analisis data terhadap hasil belajar siswa untuk aspek kognitif pada siklus I dan II menunjukkan adanya peningkatan bila dibandingkan dengan sebelum menggunakan model pembelajaran kooperatif jigsaw dengan peta pikiran. Sebelum menggunakan model pembelajaran kooperatif jigsaw dengan peta pikiran, rata-rata skor sebesar 65,67 dengan ketuntasan belajar sebesar 35,13\%. Pada siklus I rata-rata skor sebesar 68,24 dengan ketuntasan belajar sebesar 54,05\%, sedangkan pada siklus II skor rata-rata kelas sebesar 77,70 dengan ketuntasan belajar sebesar 89,18\%. Dengan demikian setelah siklus II kelas X dapat dinyatakan tuntas belajar karena telah mencapai ketuntasan lebih dari $75 \%$. Oleh sebab itu penelitian diberhentikan pada siklus II ini karena peneliti beranggapan bahwa hasil belajar sudah diatas standar ketuntasan minimal.

Menurut Dimyati \& Mundjiono (2006: 169), program pembelajaran kelompok memberikan tekanan utama pada peningkatan kemampuan individu sebagai anggota kelompok. Oleh sebab itu penilaian yang dilakukan pada kelompok bukan penilaian secara individu melainkan penilaian secara kelompok. Peningkatan kemampuan individu tersebut ditunjukkan dengan keberhasilan anggota kelompok dalam mencapai tujuan pembelajaran yang berupa ketuntasan hasil belajar. Pada pembelajaran kooperatif, keberhasilan kelompok sangat penting. Untuk mencapai hal tersebut harus didukung oleh keberhasilan individu sebagai anggota kelompok. Semakin besar tingkat keberhasilan kelompok tersebut dalam melakasanakan pembelajaran kooperatif maka semakin banyak anggota kelompok yang tuntas belajar. Pada siklus I terdapat 20 siswa yang tuntas belajar dan pada siklus II terdapat 33 siswa yang sudah tuntas belajar.

Peningkatan hasil belajar yang terjadi pada siklus II sehingga ketuntasan belajar dapat tercapai dipengaruhi oleh beberapa hal antara lain: (1) siswa memperhatikan penjelasan yang diberikan guru maupun temannya ketika melakukan diskusi kelompok; (2) siswa belajar menyelesaikan tugas dengan membuat peta pikiran dan mengerjakan tugas sesuai dengan waktu yang disediakan; (3) siswa berdiskusi dan belajar dengan sungguh-sungguh tentang materi yang sedang dipelajari untuk menyelesaikan semua tugasnya; (4) siswa belajar dengan gembira, menunjukkan sikap semangat dan senang, serta tidak melamun saat proses belajar mengajar berlangsung; (5) siswa mengerjakan semua tugas termasuk di luar sekolah yang telah diberikan guru yaitu dengan memanfaatkan jam istirahat untuk melanjutkan diskusi maupun mengerjakan tugas; (6) pada saat kegiatan diskusi, siswa tampil presentasi atau berkomunikasi dengan temannya dengan sangat tenang (tidak gugup); dan (7) siswa mempunyai sikap percaya diri ketika 
mengerjakan post-tes dengan kemampuan dirinya sendiri sehingga tidak mudah terpengaruh oleh siswa yang lain.

\section{SIMPULAN}

Berdasarkan hasil penelitian dapat disimpulkan hal-hal sebagai berikut. Pertama, penerapan model pembelajaran kooperatif jigsaw dengan peta pikiran dapat meningkatkan motivasi belajar akuntansi siswa kelas X MA Al-Ula Ambat Tlanakan Pamekasan yang ditandai dengan meningkatnya keenam indikator yaitu perhatian, lama belajar, usaha, irama perasaaan, ekstensi, dan penampilan. Kedua, penerapan model pembelajaran kooperatif jigsaw dengan peta pikiran dapat meningkatkan hasil belajar akuntansi siswa kelas X MA Al-Ula Ambat Tlanakan Pamekasan. Hal tersebut ditandai dengan peningkatan hasil belajar siswa yang diperoleh sebelum pemberian tindakan dan hasil belajar siswa setelah melakukan siklus I dan siklus II.

\section{SARAN}

Saran yang dapat dikemukakan antara lain sebagai berikut.

1. Guru dapat menggunakan model pembelajaran kooperatif jigsaw dengan peta pikiran pada pokok bahasan yang lain untuk meningkatkan motivasi dan hasil belajar akuntansi siswa.

2. Guru sebaiknya menjelaskan pentingnya materi yang akan dipelajari dan penerapannya dalam kehidupan sehari-hari sehingga siswa lebih termotivasi mengikuti kegiatan pembelajaran setelah mengetahui manfaat materi bagi kehidupannya.

3. Agar pembelajaran kooperatif jigsaw dengan peta pikiran lebih efektif, guru sebaiknya menjelaskan manfaat dan aturan main model dengan sangat jelas agar siswa mengerti tugas individu dan tugas kelompok yang harus dikerjakan, sehingga siswa termotivasi untuk bekerja sama dan berperan aktif selama pembelajaran berlangsung. Dengan demikian pembelajaran akan berlangsung dengan lancar, menyenangkan, dan penggunaan waktu secara optimal sesuai dengan rencana pembelajaran yang telah disusun. 


\section{DAFTAR RUJUKAN}

Arikunto, S. 2003. Dasar-Dasar Evaluasi Pendidikan. Jakarta: Bumi Aksara.

Buzan, Toni. 2006. Buku Pintar Mind Map. Jakarta: Gramedia.

De Porter, Bobbi dan Hernacki. 1992. Quantum Learning. Terjemahan oleh Alwiyah Abdurrahman. Bandung: Kaifa.

Dimyati \& Mudjiono. 2006. Belajar dan Pembelajaran. Jakarta: Depdikbud.

Fathurrahman, P. \& M. Sobry Sutikno. 2007. Strategi Belajar Mengajar. Bandung: PT. Refika Aditama.

Gardu Guru. 2008. Pembelajaran dengan Peta Pikiran. (Online), (http://garduguru.blogspot.com, diakses 25 Maret 2010).

Kasihani, Ibnu, S., Susiolo, H. 2006. PTK. Makalah disampaikan dalam Pelatihan Metodologi Penelitian untuk Peningkatan Kualitas Pembelajaran (PPKP) dan Penelitian Tindakan Kelas (PTK) bagi dosen-dosen LPTK se-Indonesia.

Moeslichatoen. 1992. Motivasi Dalam Proses Belajar Mengajar. Depdikbud, IKIP Malang.

Moloeng, Lexy J. 2000. Metodologi Penelitian Kualitatif. Bandung: Remaja Rosdakarya

Nashar. 2004. Teori-teori Belajar. Jakarta: Erlangga

Nurhadi, Y. B., \& Senduk, A.G. 2004. Pembelajaran Kontekstual dan Penerapannya dalam KBK. Malang: UM Press.

Sanjaya, Wina. 2005. Pembelajaran Dalam Implementasi Kurikulum Berbasis Kompetensi. Jakarta: Kencana.

Slameto. 2003. Belajar Dan Faktor-faktor Yang Mempengaruhinya. Jakarta: Rineksi Cipta.

Sudjana, N. 2001. Penilaian Hasil Proses Belajar Mengajar. Bandung: Remaja Rosdakarya.

Susanto, P. 1999. Strategi Pembelajaran Biologi di Sekolah Menengah. Malang: Universitas Negeri Malang.

Susanto, P. 2002. Keterampilan Dasar Mengajar IPA Berbasis Konstruktivisme. Malang: Jurusan Biologi FMIPA UM.

Susanto, P. 2006. Buku Petunjuk Teknis Praktik Pengalaman Lapangan Bidang Studi Winkel, W.S. 1989. Psikologi Pengajaran. Jakarta: Gramedia. 